\title{
SCREENING AND BIOCHEMICAL IDENTIFICATION OF TEF (Eragrostis tef Zucc.) Trotter) ENDOPHYTIC BACTERIAL SPECIES WITH PLANT- GROWTH-PROMOTING, BIOTIC AND ABIOTIC STRESS TOLERANCE PROPERTIES
}

\author{
Zerihun Tsegaye*., Adey Feleke., Tesfaye Alemu., and Fassil Assefa \\ Department of Microbial, Cellular and Molecular biology, Addis Ababa University, Ethiopia
}

\begin{abstract}
Endophytic bacteria play many important beneficial roles in the metabolism and physiology of the host plants, including fixing atmospheric nitrogen, solubilizing phosphates, synthesizing phytohormones, sequestrating iron, suppression of the ethylene production, and inhibiting pathogens. The present study was conducted to screen and identify endophytic bacterial species with plant growth-promotion, biotic and abiotic stress tolerance properties to develop bio inoculants. For this purpose, root and seed samples of different cultivated tef varieties were collected. A total of 195 pure endophytic bacterial colonies were isolated and screened for PGP traits, biotic and abiotic stress tolerance factors. Fourteen endophytic bacterial species or strains were identified using the Biolog microbial identification system. Among the identified endophytes, the majority of them utilized different carbon sources tagged on microplates. Three potential endophytic bacterial species or strains were evaluated for seed germination and seedling growth ability using tef seeds. Tef seeds inoculated with potential endophytes showed $100 \%$ germination performance on 3 to 4 days after inoculation. An increase in mean shoot and roots length of the inoculated seeds were observed up to 3 and $2.6 \mathrm{~cm}$ respectively. Vigor index of seedling was measured from 460 to 520 on the last day of the experiment. These promising identified tef endophytic bacterial species or strains having PGP, biotic and abiotic stress tolerance properties could be candidate organisms for the development of microbial inoculants as single strain or consortia. This strategy would work towards solving the problem of over-utilizing chemical fertilizers, and reducing environmental pollution while increasing the yield and productivity of tef crops and other agricultural plants.
\end{abstract}

Keywords: Bioinoculants, Biolog, Endophyte, Plant growth promotion, Tef 


\subsection{INTRODUCTION}

Tef (Eragrostis tef (Zucc). Trotter) is an indigenous cereal crop of Ethiopia and has been cultivated for thousands of years in Ethiopian highlands [1]. It is a daily staple food for the majority of Ethiopians. Shahidur indicated that tef has strong inseparable cultural and traditional ties for more than ninety million of Ethiopians. Roots and seeds of tef crop harbor endophytic microorganisms [2], which have significant roles in plant growth promotion and biocontrol activity.

Crops are naturally associated with diverse groups of microorganisms in various ways. One group of these is endophytes, which can colonize internal tissues of host plants including aboveground and underground parts without damaging host cells [3]. Endophytes can be isolated from surface-sterilized plant tissues and do not visibly damage the host plant [4]. It may play important characters in the metabolism and physiology of the host plants.

Bacterial endophytes which can colonize a plant's interior and establish a special type of relationship where both partners may derive benefits from this interaction [5]. Its colonization refers to the entry, growth, and multiplication of endophyte populations within the host plant [6]. Root exudates likely contain substance that initiate early communication between host plants and endophytes and consequently steer the colonization process [7]. Also, bacterial quorum sensing compounds are likely involved in communication with the plant root and the following colonization process [8].

The attachment or adhesion of bacterial cells to the plant surface is considered as the first step of the colonization process [8]. Bacterial species which are originated in the locality of the plant roots most likely swim towards the roots, using chemotactic attractions for root exudates. This is followed by bacterial attachment to the root surface, which is likely essential in getting access to potential entry sites at the lateral root emergence regions or other openings caused by wounds or mechanical damages. The exopolysaccharides (EPS) produced by bacterial cells may facilitate the attachment of bacterial cells onto the plant root surface and may be essential in the early stages of endophytic bacterial colonization.

The EPS produced by endophytic bacterial strain such as Gluconacetobacter diazotrophicus Pal5 was stated as an important factor for rice root surface attachment and colonization [9]. Polysaccharide is found in different bacterial structures such as flagella, fimbriae or cell surface are involved in attachment to the host plant surface [10]. Studding the colonization of maize plants by endophyte $H$. seropedicae, Balsanelli et al. [10] reported that bacterial lipopolysaccharide (LPS) is essential for attachment and following endophytic colonization of plant roots. Later, it was also demonstrated that the binding of $\mathrm{N}$-acetyl glucosamine of LPS with maize root lectins is necessary for bacterial attachment and subsequent colonization inside the plant roots [11].

Bacterial endophytes initially attach to the root surface also called rhizoplane, and explore the potential entry sites to access the internal plant tissues. Openings in the roots where root hairs or lateral roots emerge, as well as stomata, wounds, and hydathodes in the shoots, are considered the main entry points that endophytes use to enter the host plant [12]. Endophytic bacteria likely use these natural discontinuities in the host plant body to access the internal plant tissues. Furthermore, some bacterial endophytes may modify the plant cell wall by synthesizing cell wall cellulolytic enzymes such as cellulases, protease, xylanases, pectinases, and endoglucanases, which facilitate bacterial entry and spread within the plant tissues [13]. One study supported this hypothesis by observing that the 
frequency of entry of an endoglucanase mutant of Azoarcus sp. BH72 into rice roots was declined as compared to the wild type strain and the mutant was unable to spread to the aerial plant parts [14].

Bacterial endophytes have been reported to promote plant growth and protect from diseases causing organisms by several different mechanisms [15]. These mechanisms include synthesizing plant-growthpromoting hormones such as indole-3-acetic acid (IAA), cytokinins and gibberellins. Furthermore, bacterial endophytes secrete siderophores and solubilize phosphorus [16]. Similarly, phosphorussolubilizing bacteria can solubilize immobile phosphorus, which is potentially available for plants to absorb, an important trait for plant growth promotion (PGP) [17]. Some none symbiotic bacterial endophytes are carrying genes necessary for biological nitrogen fixation (BNF), potentially enabling them to convert dinitrogen gas $\left(\mathrm{N}_{2}\right)$ into usable forms of nitrogen such as ammonium and nitrate within the host plant [18]. Bacterial endophytes can confer resistance or tolerance to the host plant from biotic and abiotic stresses by releasing antimicrobial compounds, secreting different types of lytic enzymes, producing siderophores, hydrogen cyanide (HCN), EPS, LPS, competing for space and nutrients, and modulating the plant resistance response [19]. Some bacterial strains can relieve plant stress by blocking the pathway of ethylene synthesis in plants. These bacteria utilize 1-aminocyclopropane-1-carboxylate (ACC) deaminase, which helps to reduce ethylene concentrations accumulated in response to different stresses in plants, otherwise lethal to plant health [20]. The objective of the present study was to screen and identify tef crop colonizing endophytes with plant growth stimulating and biocontrol properties to make efficient bioinoculant to sustain crops productivity and grain quality improvement.

\subsection{MATERIALS AND METHODS}

\section{Study area and time}

This study was conducted in East Shewa Zone, Oromia Regional State, Ethiopia from 2010 to 2011

E.C. According to zonal statistics and information center, the zone is found between $38^{\circ} 57^{\prime}$ and $39^{\circ} 32^{\prime}$

E and $7^{\circ} 12^{\prime}$ and $9^{\circ} 14^{\prime} \mathrm{N}$ [figure1.]
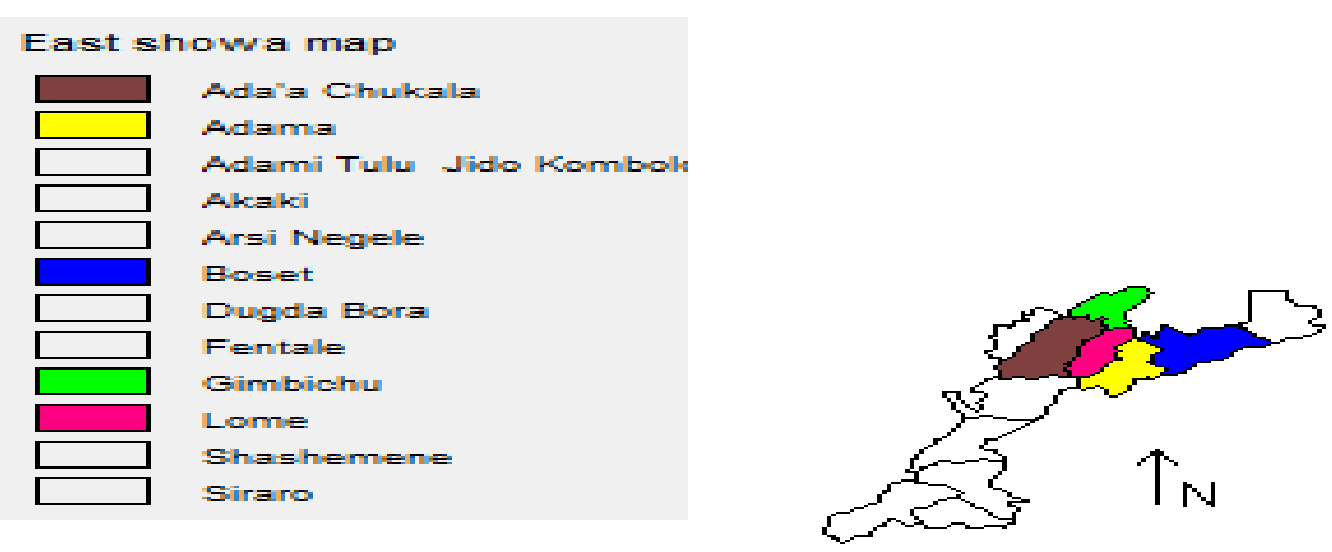

Figure: Map of the study area

\section{Sample size and type}


A total of 213 root samples of different cultivated tef varieties found at seedling and flowering stages were collected along with the different altitudinal ranges and 370 seed samples were also collected during the maturity stage.

\section{Endophytic bacterial isolation}

In order to isolate endophytic bacteria, root and seed samples were surface sterilized using $70 \%$ ethanol for 3 minutes, followed with $1 \%$ sodium hypochlorite for 5 minutes and washed with distilled water. An aliquot of $0.1 \mathrm{~mL}$ sample of the roots and seeds washed water from the fifth rinse was plated on nutrient agar medium (Peptone, beef extract \& agar) [21] to verify the efficiency of surface sterilization. Treated roots and seeds were dried in the oven and crushed using sterile mortar and pestle. Roots and seeds powder were added in to test tubes containing $9 \mathrm{ml}$ of normal saline $(0.9 \% \mathrm{NaCl})$ and vortexed for 5 minutes to make a solution. The homogenized root and seed solutions were serially diluted $\left(10^{-1}\right.$ to $10^{-}$ ${ }^{6}$ ) aseptically and transferred on to prepared agar media and incubated $30^{\circ} \mathrm{C}$ for 24 to 48 hours to isolate pure endophytic bacterial colonies.

\section{Phosphate solubilization, IAA production, Nitrogen fixation and ammonia production activities of endophytic bacterial}

\section{Phosphate solubilization (PS)}

Endophytic bacterial isolates of tef roots and seeds were screened for their phosphate solubilizing activity using Pikovaskaya's medium. The cultures were spot-inoculated on the Pikovskay's medium plates and incubated at $30^{\circ} \mathrm{C}$ for 3 to 5 days. The appearance of a clear zone around bacterial growth shows a positive result for bacterial phosphate solubilization ability [22]. Phosphate solubilization index was determined using the following formula.

Solubilization index $(\mathrm{SI})=\underline{\text { Colony diameter }+ \text { halo zone diameter }}$

Colony diameter

\section{Production of IAA:}

IAA production was detected as described by Brick et al., (2015) [23]. Endophytic bacterial cultures were grown on their respective media modified with $100 \mathrm{mg} / \mathrm{L}$ tryptophan as the precursor of IAA and incubated in a shaker at $250 \mathrm{rpm}$ at $30^{\circ} \mathrm{C}$ for 3 to 4 days. Fully grown bacterial cultures were centrifuged at three thousand $\mathrm{rpm}$ for thirty minutes. The supernatant $(2 \mathrm{ml})$ was mixed with two drops of orthophosphoric acid and $4 \mathrm{ml}$ liter of the Salkowski reagent $(50 \mathrm{ml}, 35 \%$ of perchloric acid, $1 \mathrm{ml}, 0.5$ $\mathrm{M} \mathrm{FeCl}_{3}$ solution). An appearance of pink color formation is a positive result for endophytic bacterial IAA production ability.

\section{Nitrogen fixation (NF)}

Endophytic bacterial isolates were screened for atmospheric nitrogen-fixing ability using the nitrogenfree basal medium. Endophytic bacterial growth on the nitrogen-free medium was used as an indicator of bacterial atmospheric nitrogen fixation property [24].

\section{Ammonia production (AP)}


Endophytic bacterial isolates were screened for the production of ammonia using peptone water. Freshly grown endophytic bacterial cultures were inoculated in $10 \mathrm{ml}$ peptone water containing tubs and incubated at $30^{\circ} \mathrm{C}$ for $72 \mathrm{~h}$. Nessler's reagent was added to each tube. Formations of brown to yellow color indicate a positive result for bacterial ammonia production [25].

\section{Endophytic bacteria screened for lytic enzyme production, HCN production and exopolysaccharide production}

\section{Test for HCN production:}

The isolates were inoculated on the nutrient media plates containing $4.4 \mathrm{~g}$ glycine/L. To the top of the plate, Whatman filter paper no. 1 soaked in $2 \%$ sodium carbonate in $0.5 \%$ picric acid solution was placed and sealed with parafilm. The plates were incubated at $30^{\circ} \mathrm{C}$ for 4 days. Plates were observed for the formation of orange to red color of filter paper. These indicate positive results for bacterial $\mathrm{HCN}$ production [26].

\section{Test for lytic enzymes production}

Endophytic bacterial isolates were screened for lytic enzyme synthesis such as amylase, protease, and cellulose,

\section{Test for bacterial amylase synthesis}

Endophytic bacterial pure cultures were spot inoculated on starch agar (Beef extract $3.0 \mathrm{~g}$, peptone 5.0 $\mathrm{g}$, soluble starch $2.0 \mathrm{~g}$, Agar $15.0 \mathrm{~g}$, distilled water $1 \mathrm{~L}$ ) medium plates and incubated at $30^{\circ} \mathrm{C}$ for $48 \mathrm{~h}$. At the end of the incubation period, the plates were flooded with iodine solution, kept for a minute and then poured off. Iodine reacts with starch to form a blue color compound. This blue color fades rapidly. Hence the colorless zone surrounding colonies indicates bacterial amylase production [27].

\section{Test for bacterial protease production}

Tef roots and seeds endophytic bacterial isolates were tested for their ability to produce protease onto skim milk agar (SMA) (3\% v/v) medium [28]. The diameter of the clear zone made around the bacterial colonies was measured after forty eight hour of incubation at $30^{\circ} \mathrm{C}$. Bacterial pure colon showing a clear zone on the protease testing medium was showed a positive result for bacterial protease enzyme synthesis.

\section{Test for bacterial cellulase production}

Endophytic bacterial isolates were tested for cellulase production activity by spot inoculation on the cellulose agar media with the following composition [29]: $\mathrm{KH}_{2} \mathrm{PO}_{4} 0.5 \mathrm{~g}, \mathrm{MgSO}_{4} 0.25 \mathrm{~g}$, cellulose $2 \mathrm{~g}$, agar $15 \mathrm{~g}$, and gelatin $2 \mathrm{~g}$; distilled water $1 \mathrm{~L}$ and at $\mathrm{pH}$ 6.8-7.2. The use of Congo-red as an indicator of cellulose degradation in an agar medium provides the basis for a rapid and sensitive screening test for cellulolytic bacteria. Bacterial isolates showing a clear halo zone on cellulose medium was indicated a positive result for bacterial cellulase synthesis.

\section{Test for EPS production}

Tef roots and seeds endophytic bacterial cultures were screened for EPS synthesis using Burk's medium (g/L: Sucrose, 20.0; $\mathrm{K}_{2} \mathrm{HPO}_{4}, 0.80 ; \mathrm{KH}_{2} \mathrm{PO}_{4}, 0.20 ; \mathrm{MgSO}_{4} .7 \mathrm{H}_{2} 0,0.20 ; \mathrm{NaCl}, 0.20 ; \mathrm{CaSO}_{4}, 0.10,0.1 \mathrm{ml}$ of Fe-Mo Mixture $\left(\mathrm{FeCl}_{3} .6 \mathrm{H}_{2} \mathrm{O} 1.45 \mathrm{~g}\right.$ and $\mathrm{Na}_{2} \mathrm{MoO} 4.2 \mathrm{H}_{2} \mathrm{O}, 0.253 \mathrm{~g}$ in $\left.100 \mathrm{ml}\right), \mathrm{H}_{3} \mathrm{BO}_{3}, 10 \mu \mathrm{g} ; \mathrm{ZnSO}_{4}$, $10 \mu \mathrm{g} ; \mathrm{MnSO}_{4}, 1 \mu \mathrm{g} ; \mathrm{CUSO}_{4} .5 \mathrm{H}_{2} \mathrm{O}, 0.3 \mu \mathrm{g} ; \mathrm{KI}, 0.1 \mu \mathrm{g}$ and Agar 25.0) and detected for endophytic 
bacterial pure culture mucoid colony formation. And also, bacterial pure colonies were extracted and confirmed for precipitate formation using cold acetone indicating bacterial EPS synthesis [30]

\section{Effect of different salt concentration, $\mathrm{pH}$ and temperature on endophytic bacterial growth}

Tef roots and seeds endophytic bacterial isolates were screened for different concentration of salt, $\mathrm{NaCl}$ $(5 \%, 10 \%, 15 \%$ and $20 \% \mathrm{w} / \mathrm{v})$, different $\mathrm{pH}$ ranges $(4,5,7,9,11$ and 13$)$ and different temperature ranges $\left(4^{\circ} \mathrm{C}, 20^{\circ} \mathrm{C}, 30^{\circ} \mathrm{C}, 40^{\circ} \mathrm{C}, 50^{\circ} \mathrm{C}\right.$ and $\left.60^{\circ} \mathrm{C}\right)$ respectively.

\section{Biolog bacterial biochemical characterization and identification}

Identification of cultivable plant growth-promoting endophytic bacterial was performed using morphological characterization and basic biochemical tests. For colonial morphology characterization, bacterial isolates were grown on peptone agar medium for 24 to 48 hours at $30^{\circ} \mathrm{C}$ and characterized for their following traits: color, shape, length, surface, opacity, and texture. For cellular morphology i.e. size and division mode were evaluated by performing phase-contrast microscopy. Carbon source utilization and oxidation patterns of the endophytic bacteria were analyzed by BIOLOG system® (EBI) using Gene III Biolog microplates [31].

\section{Effects of tef endophytic bacteria on seed germination and seedling growth}

Bacterial seed germination capacity was evaluated to determine the effect of endophytes on the rates of seed germination and seedling growth status. For this, tef seeds were used as plant materials. Pure tef seeds were surface sterilized with seventy percent ethanol for three minutes and followed with one percent hypochlorite for five minutes and wished five times with sterile distilled water. Three tef endophytic bacterial species (single and consortium) having the best PGP traits were used. Selected species were grown in nutrient broth on shaking incubator $(180 \mathrm{rpm})$ at $30^{\circ} \mathrm{C}$ for $24 \mathrm{~h}$. The surfacesterilized seeds of tef were inoculated in broth culture containing bacterial species for thirty minutes including sterile water as control. Twenty-five inoculated seeds of each treatment were placed in separate petri-plate containing soaked filter papers and the petri-plates were incubated at room temperature for seven days. Seed germination was recorded regularly starting from the $2^{\text {nd }}$ day after inoculation based on the number of germinated seed out of total germination. Each treatment was replicated three times. Percentages of seed germination and seedling growth were calculated. The effect of single and consortium-seed bacterization on shoot and root growth status was evaluated and the vigor index of seedling was measured on the last day of the experiment according to the formula proposed by Abul-Baki and Anderson [32].

\section{Compatibility test}

Bacterial cultures were streaked on nutrient agar plates in such a way that for every single bacterial culture in the center of the plate, other cultures are streaked radiating from the center. The plates were incubated at $37^{\circ} \mathrm{C}$ for $48 \mathrm{~h}$ and the zone of inhibition was observed and recorded

\section{Methods of data analysis}

Data analysis was conducted to evaluate cultivable endophytic bacterial isolates for bacterial phosphate solubilization, nitrogen fixation, IAA production, ammonia production, lytic enzyme production, HCN production and EPS synthesis, and also evaluate tolerance to different concentration of salts, $\mathrm{pH}$ and temperature. 


\subsection{RESULTS}

\section{Isolation}

One hundred and twenty bacterial isolates from roots and seventy - five from seeds were obtained and characterized for cultural morphological traits (size, shape, color, margin, elevation, and opacity) and for cellular morphology i.e. bacterial color and shape were determined using light microscopy. The highest percentage occurrences of the tef endophytic bacterial pure colonies on culture media, $90 \%$ (176) were gram-negative and $10 \%$ (19) were gram-positive, and based on bacterial division, $85.7 \%$ (12) were Proteobacteria phylum and14.3\% (2) were Firmicutes phylum.

\section{Phosphate solubilization (PS), IAA production, Nitrogen fixation (NF) and ammonia (AP) production activities of endophytic bacterial}

Among these $77.9 \%$ (152) bacterial pure colonies were positive for phosphate solubilization, $59.5 \%$ (116) colonies were positive for IAA production, $9.7 \%$ (19) colonies were positive for ammonia production, and $9 \%$ (17) colonies were grown well on nitrogen free medium (Table.1)

Table.1: PS, IAA production, NF and ammonia production (AP) activities of bacteria

\begin{tabular}{|c|c|c|c|c|c|}
\hline \multirow[t]{2}{*}{ Code } & \multicolumn{2}{|l|}{ PS } & \multirow[t]{2}{*}{ IAA production } & \multirow[t]{2}{*}{ NF } & \multirow[t]{2}{*}{$\mathbf{A P}$} \\
\hline & & (SI) & & & \\
\hline $1^{\text {st }} f$ TRE- 8 & +++ & 2.85 & +++ & + & + \\
\hline $1^{\text {st }} f$ TRE-21 & +++ & 2.88 & +++ & - & - \\
\hline $1^{\text {st }} f$ TRE-53 & ++ & 2.22 & ++ & - & - \\
\hline $2^{\text {nd }} f$ TRE- $1^{\text {st }}$ & +++ & 2.7 & + & - & - \\
\hline $2^{\text {nd }} f$ TRE-4 & ++++ & 3.3 & ++ & + & +++ \\
\hline $2^{\text {nd }} f$ TRE- 28 & +++ & 2.8 & +++ & + & ++ \\
\hline $2^{\text {nd }} f$ TRE-43 & +++ & 2.6 & ++ & + & +++ \\
\hline $2^{\text {nd }} f$ TRE-66 & ++ & 2.4 & + & - & - \\
\hline $2^{\text {nd }} f$ TRE-74 & + & 1.9 & +++ & - & + \\
\hline $2^{\text {nd }} f$ TRE-86 & ++ & 2.4 & +++ & - & - \\
\hline SE-3 & ++++ & 3.1 & ++++ & + & + \\
\hline SE-10 & ++ & 2.2 & + & - & - \\
\hline SE-22 & ++ & 2.3 & ++ & - & - \\
\hline SE- $\left(8^{\text {nd }}\right)$ & ++ & 2.3 & + & + & ++ \\
\hline
\end{tabular}

$++++($ very strong $),+++($ strong $),++($ moderate $),+($ poor $)$ and $-($ negative $)$ 


\section{Lytic enzyme, HCN and EPS production of endophytic bacteria}

From one hundred and ninety-five endophytic bacterial isolates, among these $14.4 \%$ (28) isolates were positive for protease production, $14.9 \%$ (29) colonies were positive for amylase and $12.3 \%$ (24) colonies were positive for cellulase production. $6.2 \%$ (12) colonies were positive for HCN and $11 \%$ (21) colonies were positive for EPS production (Table 2).

Table.2: Endophytic bacteria screened for lytic enzyme (LE), HCN and EPS production

\begin{tabular}{|c|c|c|c|c|c|}
\hline \multirow[t]{2}{*}{ Code } & \multicolumn{3}{|l|}{$\mathbf{L E}$} & \multirow{2}{*}{$\begin{array}{l}\text { HCN } \\
\text { production }\end{array}$} & \multirow[t]{2}{*}{ EPS } \\
\hline & amylase & protease & cellulase & & \\
\hline $1^{\text {st }}$ f TRE-8 & ++ & + & + & + & +++ \\
\hline $1^{\text {st }} f$ TRE-21 & - & + & - & - & ++ \\
\hline $1^{\text {st }} f$ TRE-53 & + & + & - & - & + \\
\hline $2^{\text {nd }} f$ TRE $-1^{\text {st }}$ & + & +++ & + & - & + \\
\hline $2^{\text {nd }} f$ TRE-4 & + & + & - & + & ++ \\
\hline $2^{\text {nd }} f$ TRE-28 & +++ & ++ & + & +++ & +++ \\
\hline $2^{\text {nd }} f$ TRE-43 & + & + & - & +++ & ++ \\
\hline $2^{\text {nd }} f$ TRE-66 & - & + & - & +++ & + \\
\hline $2^{\text {nd }} f$ TRE- 74 & + & + & - & + & ++ \\
\hline $2^{\text {nd }} f$ TRE- 86 & - & + & + & +++ & + \\
\hline SE-3 & ++ & + & - & + & ++ \\
\hline SE-10 & + & + & - & - & + \\
\hline SE-22 & + & ++ & + & + & + \\
\hline SE- $\left(8^{\text {nd }}\right)$ & +++ & + & + & + & +++ \\
\hline
\end{tabular}

+++ (strong), ++ (moderate),+ (poor) and - (negative)

Effect of different salt concentration, $\mathrm{pH}$ and temperature on endophytic bacterial growth

One hundred and ninety-five endophytic bacterial pure colonies were screened for effect of different salt concentration, $\mathrm{pH}$ and different temperature range. Among them, all bacterial isolates were grown well at neutral $\mathrm{pH}$ and at $30^{\circ} \mathrm{C}$. None of the bacterial isolates were survived at $\mathrm{pH}-13$ and at $60^{\circ} \mathrm{C}$. Around $36.9 \%$ of isolates were grown well on media containing $5 \% \mathrm{NaCl}, 12.8 \%$ of isolates on $10 \%$ $\mathrm{NaCl}, 11.3 \%$ of isolates on $15 \% \mathrm{NaCl}$ and $6.2 \%$ of isolates on $20 \% \mathrm{NaCl}$ concentration. Around $46.2 \%$ of isolates were grown well at $\mathrm{pH}-5,8.7 \%$ of isolates were grown well at $\mathrm{pH}-4,4.6 \%$ isolates were grown well at $\mathrm{pH}-11 \mathrm{and}, 36.4 \%$ of isolates were grown well at $40^{\circ} \mathrm{C}$, and only $1 \%$ of isolates were grown well at $50^{\circ} \mathrm{C}$ (Tale.3). 
Table.3: Effect of different salt concentration, $\mathrm{pH}$ and temperature on endophytic bacterial growth

\begin{tabular}{|c|c|c|c|c|c|c|c|c|c|c|c|c|}
\hline \multirow{2}{*}{$\begin{array}{l}\text { Code of the } \\
\text { isolates }\end{array}$} & \multicolumn{3}{|c|}{ Salinity tolerance } & \multicolumn{4}{|c|}{$p^{\mathrm{H}}$ tolerance } & \multicolumn{5}{|c|}{ Temperature tolerance } \\
\hline & $5 \%$ & $10 \%$ & $15 \%$ & $20 \%$ & 45 & $\begin{array}{ll}9 & 11\end{array}$ & 13 & 420 & 30 & 40 & 50 & 60 \\
\hline $1^{\text {st }}$ f TRE-8 & $\sqrt{ }$ & $\times$ & $x$ & $x$ & $\times \sqrt{ } \sqrt{ }$ & $\sqrt{x}$ & $\times$ & $\sqrt{ }$ & $\sqrt{ }$ & $x$ & $x$ & $x$ \\
\hline $1^{\text {st }} f$ TRE-21 & $\sqrt{ }$ & $\sqrt{ }$ & $x$ & $x$ & $\times \sqrt{ } \sqrt{ }$ & $\sqrt{x}$ & $\times$ & $\times \sqrt{ }$ & $\sqrt{ }$ & $\sqrt{ }$ & $x$ & $x$ \\
\hline $1^{\text {st }}$ f TRE-53 & $\sqrt{ }$ & $\sqrt{ }$ & $\sqrt{ }$ & $\sqrt{ }$ & $\times \sqrt{ } \sqrt{ }$ & $\sqrt{x}$ & $x$ & $\times \sqrt{ }$ & $\sqrt{ }$ & $\sqrt{ }$ & $x$ & $x$ \\
\hline $2^{\text {nd }} f \mathrm{TRE}-1^{\text {st }}$ & $\sqrt{ }$ & $x$ & $x$ & $x$ & $\times \sqrt{ } \sqrt{ }$ & $\times \times$ & $x$ & $\times \sqrt{ }$ & $\sqrt{ }$ & $\sqrt{ }$ & $x$ & $x$ \\
\hline $2^{\text {nd }} f$ TRE-4 & $\sqrt{ }$ & $\times$ & $x$ & $x$ & $\times \sqrt{ } \sqrt{ }$ & $\times \times$ & $x$ & $\times \sqrt{ }$ & $\sqrt{ }$ & $\sqrt{ }$ & $x$ & $x$ \\
\hline $2^{\text {nd }} f$ TRE- 28 & $\sqrt{ }$ & $\sqrt{ }$ & $x$ & $x$ & $\times \sqrt{ } \sqrt{ }$ & $\sqrt{x}$ & $x$ & $\sqrt{ }$ & $\sqrt{ }$ & $x$ & $x$ & $x$ \\
\hline $2^{\text {nd }} f$ TRE-43 & $\sqrt{ }$ & $\times$ & $x$ & $x$ & $\times \sqrt{ } \sqrt{ }$ & $\times \times$ & $\times$ & $\sqrt{ }$ & $\sqrt{ }$ & $x$ & $x$ & $x$ \\
\hline $2^{\text {nd }} f$ TRE-66 & $\sqrt{ }$ & $\sqrt{ }$ & $x$ & $x$ & $x \sqrt{ } \sqrt{ }$ & $\times \times$ & $x$ & $\times \sqrt{ }$ & $\sqrt{ }$ & $x$ & $\times$ & $x$ \\
\hline $2^{\text {nd }} f$ TRE-74 & $\sqrt{ }$ & $\sqrt{ }$ & $x$ & $x$ & $\times \times \sqrt{ }$ & $\times \times$ & $\times$ & $\times \sqrt{ }$ & $\sqrt{ }$ & $\sqrt{ }$ & $x$ & $x$ \\
\hline $2^{\text {nd }} f$ TRE-86 & $\sqrt{ }$ & $x$ & $x$ & $x$ & $\times \sqrt{ } \sqrt{ }$ & $\times \times$ & $x$ & $\sqrt{ }$ & $\sqrt{ }$ & $x$ & $x$ & $x$ \\
\hline SE-3 & $\sqrt{ }$ & $x$ & $x$ & $x$ & $\times \sqrt{ } \sqrt{ }$ & $\sqrt{ }$ & $x$ & $\times \sqrt{ }$ & $\sqrt{ }$ & $\sqrt{ }$ & $x$ & $x$ \\
\hline SE-10 & $\sqrt{ }$ & $\sqrt{ }$ & $\sqrt{ }$ & $x$ & $\sqrt{ } \sqrt{ }$ & $\sqrt{ }$ & $x$ & $\sqrt{ }$ & $\sqrt{ }$ & $\sqrt{ }$ & $x$ & $x$ \\
\hline SE-22 & $\sqrt{ }$ & $\sqrt{ }$ & $\sqrt{ }$ & $\sqrt{ }$ & $\times \times \sqrt{ }$ & $\times \times$ & $\times$ & $\times \sqrt{ }$ & $\sqrt{ }$ & $x$ & $x$ & $x$ \\
\hline SE- $8^{\text {nd }}$ & $x$ & $x$ & $x$ & $x$ & $\times \sqrt{ } \sqrt{ }$ & $\times \times$ & $x$ & $\times \quad \sqrt{ }$ & $\sqrt{ }$ & $\sqrt{ }$ & $\sqrt{ }$ & $x$ \\
\hline
\end{tabular}

$\sqrt{ }($ growth $), \times($ not growth)

\section{Biolog bacterial biochemical characterization and identification}

Biolog Gene III microplates filled with 71 different carbon sources and classified into six categories i.e. polymers (dextrin, $\beta$-cyclodextrin ), carbohydrates ( $\alpha$-D-glucose, D-sorbitol, D-fructose, maltose, sucrose, arbutin, gentiobiose, and 3-methyl-glucose), carboxylic acids (pyruvic acid, lactic acid, acetic acid, citric acid, methyl pyruvate, and mono-methyl-succinate), amide and amine (succinamic acid, Lalaninamide, and putrescine), amino acids (D-alanine, L-alanine, L-asparagine, and L-glutamic acid and L-serine), and miscellaneous (salicin, glycerol, 2,3-butanediol, 2'-deoxyadenosine, inosine, tween 80 and uridine). From 71 different carbon sources tagged into the gene II microplates, only 24 carbon sources were utilized by the majority of tef endophytic bacterial isolates. Among them $92.9 \%$, endophytic bacterial isolates utilized L-Glutamic acid, D-Guluconic acid, acetic acid, and L-malic acid. $85.7 \%$ of isolates were utilized L-aspartic acid. Around $78.6 \%$ of isolates utilized L-alanine, LHistidine, L-Lactic acid, and citric acid. About $71.4 \%$ of isolates utilized $\alpha$-D-glucose, D-Glucuronic acid, and Quinic acid and identified to the species level. Around $64.3 \%$ of isolates utilized L-Serine. About $57.1 \%$ of isolates utilized D-fructose and L-Arginine and identified to the species level. About $50 \%$ isolates utilized D-galactose, glycerol and propionic acid and identified to the species level. 
Around $42.9 \%$ of isolates utilized D-mannose, D-mannitol, and methyl pyruvate and identified to the species. About $35.7 \%$ of isolates utilized sucrose, pectin, and N-acyl-D-glucosamine and identified to the species (Table. 4).

Table.4: Biolog bacterial biochemical characterization and identification

\begin{tabular}{|c|c|c|c|c|c|c|c|c|c|c|c|c|c|c|}
\hline \multirow{2}{*}{$\begin{array}{l}\text { Carbon source } \\
\text { utilized by PGP } \\
\text { bacterial species }\end{array}$} & \multicolumn{14}{|c|}{ Identified plant growth promoting bacterial species or strains } \\
\hline & 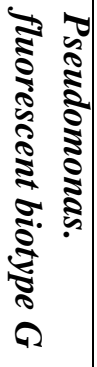 & 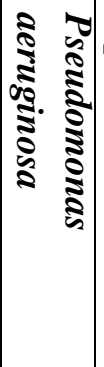 & 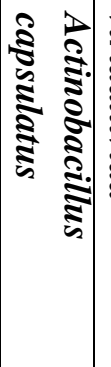 & 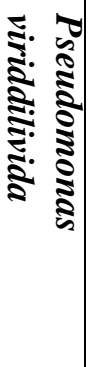 & 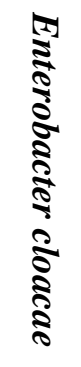 & 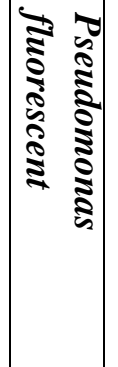 & 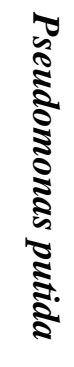 & 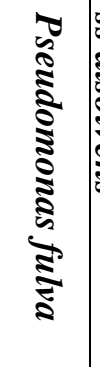 & 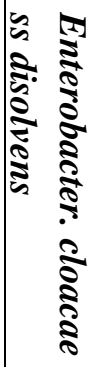 & 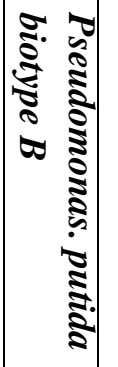 & 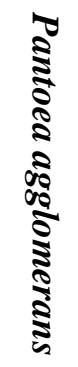 & 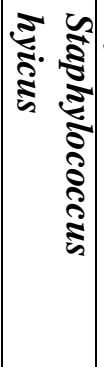 & 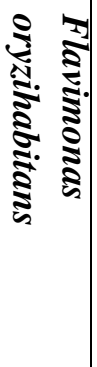 & 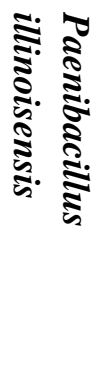 \\
\hline sucrose & - & - & - & - & + & - & - & - & + & - & + & + & - & + \\
\hline $\begin{array}{l}\text { N-Acetyl-D- } \\
\text { glucosamine }\end{array}$ & - & - & - & - & + & - & - & - & + & - & + & + & - & + \\
\hline$\alpha$-D-glucose & + & + & - & + & - & + & - & + & + & - & + & + & + & + \\
\hline D-Mannose & + & - & - & - & + & - & - & - & + & - & - & + & + & + \\
\hline D-Fructose & + & + & - & - & + & - & - & - & + & - & + & + & + & + \\
\hline D-Galactose & - & - & + & - & + & - & - & - & + & - & + & + & + & + \\
\hline D-Manitol & + & + & - & - & + & - & - & - & + & - & - & - & + & + \\
\hline Glycerol & + & + & - & - & + & - & - & - & + & - & + & - & + & + \\
\hline L-Alanine & + & + & + & + & + & + & + & - & + & + & + & - & + & - \\
\hline L-Arginine & + & + & + & + & - & + & + & - & - & + & - & + & - & - \\
\hline L-Aspartic acid & + & + & + & + & + & + & + & - & + & + & + & + & + & - \\
\hline L-Glutamic acid & + & + & + & + & + & + & + & + & + & + & + & + & + & - \\
\hline L-Histidine & + & + & + & + & + & + & + & - & + & + & + & + & - & - \\
\hline L-Serine & + & + & + & - & + & - & + & - & + & + & - & + & + & - \\
\hline Pectin & - & - & - & - & + & - & - & - & + & - & + & + & - & + \\
\hline D-Gluconic acid & + & + & - & + & + & + & + & + & + & + & + & + & + & + \\
\hline D-Glucuronamide & - & + & + & + & - & + & + & + & + & + & + & - & + & - \\
\hline Quinic acid & + & + & + & + & - & + & + & + & - & + & + & - & + & - \\
\hline Methyl pyruvate & - & & + & + & + & - & - & - & + & - & - & + & + & - \\
\hline
\end{tabular}




\begin{tabular}{lcccccccccccccccc}
\hline L-Lactic acid & + & + & + & - & + & + & + & - & + & + & + & + & + & - \\
\hline Citric acid & + & + & + & - & + & + & + & + & + & + & - & + & + & - \\
\hline L-Malic acid & + & + & + & + & + & + & + & + & + & + & + & + & + & - \\
\hline Propionic acid & + & + & + & + & - & + & + & - & - & + & - & - & - & - \\
\hline Acetic acid & + & + & + & + & - & + & + & + & + & + & + & + & + & + \\
\hline Probability (\%) & 62 & 47 & 45 & 37 & 51 & 63 & 60 & 30 & 37 & 80 & 72 & 32 & 95 & 32 \\
\hline
\end{tabular}

$+($ utilized) \& - (not utilized)

\section{Effects of tef endophytic bacteria on seed germination and seedling growth}

Seed germination and seedling growth evaluation was performed using 3 bacterial species having excellent plant growth promoting traits, biotic and abiotic stress tolerance properties. Seed coating was done using single and consortium bacterial inoculation system and seeds germination rate and growth status were calculated. These 3-plant growths promoting bacterial species or strains such as Pseudomonas fluorescence biotype G, Pseudomonas fluorescens and Pantoae agglomerans inoculated seeds recorded $100 \%$ germination 3 to 4 days after inoculation. Measurement of shoot and root length was carried out to determine the effect of single and co-inoculation of plant growth promoting bacterial species as follows; five seedlings were randomly selected from each Petri dish and measured with a measuring tape and expressed in centimeters (18). Measurement was taken after 7 days of seed set. Endophytic plant growth promoting bacterial species or strains inoculated seeds showed increase mean shoots (MSL) and roots length (MRL) up to $3 \mathrm{~cm}$ and $2.5 \mathrm{~cm}$ respectively in comparison to control and seed vigor index from 460 up to 520 at the last day of the experiment (Table.5).

Table.5: Seeds germination and seedling growth

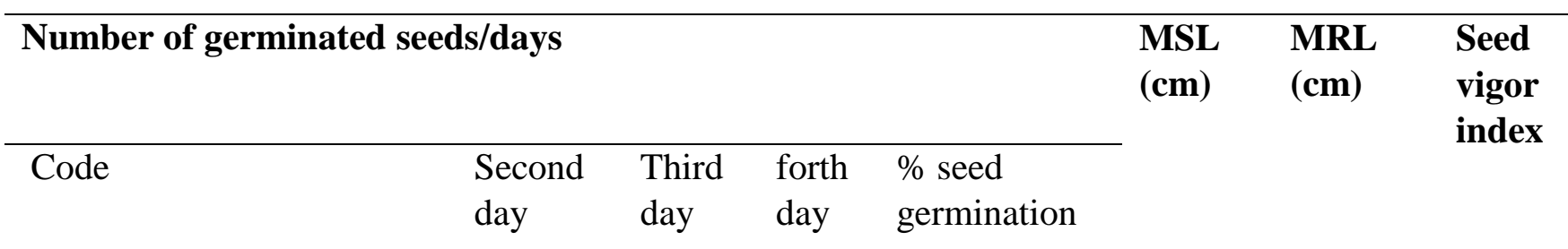

\begin{tabular}{lccccccc}
\hline P. fluorescence biotype $G$ & 12 & 23 & 25 & 100 & 2.2 & 2.5 & 470 \\
\hline P. fluorescens & 13 & 25 & 25 & 100 & 2.6 & 2.4 & 500 \\
\hline Pantoae agglomerans & 10 & 20 & 25 & 100 & 2.5 & 2.1 & 460 \\
\hline Consortium & 13 & 25 & 25 & 100 & 3.0 & 2.2 & 520 \\
\hline Control & 8 & 20 & 20 & 80 & 1.8 & 2.3 & 410 \\
\hline
\end{tabular}




\subsection{DISCUSSION}

The use of PGP endophytes offers an opportunity to maximize crop productivity while reducing utility of chemical fertilizer as well as environmental problem. In the present study, a total of 195 endophytic bacterial pure colonies were isolated. The percentage occurrences of the tef endophytic bacterial isolates on culture media, $90 \%$ (176) were gram-negative and $10 \%$ (19) were gram-positive. The endophytes were screened for their multiple plant growth promoting, biotic and abiotic stress tolerance properties. Totally 14 PGP bacterial species or strains were identified using Biolog microbial identification system based on Carbone utilization and oxidation $[1,2 \& 3]$

In agricultural soils phosphorus availability to the plants is very limited because the majority of phosphorus present in the plant unavailable form. Most of the unavailable forms of Phosphorus exist as calcium phosphate and magnesium Phosphates in alkaline soils and aluminum Phosphate and iron Phosphate in acidic soils [33]. Endophytic bacteria species or strains can improve plant growth by the action of the organic acids production [37] and chelation of cations like calcium ions that release organic phosphorus and make it available to plant use. The present study revealed $77.9 \%$ bacterial isolates were solubilized Phosphorus with the highest Phosphate solubilizing efficiency and could be used as bacterial inoculums to improve yield of the tef crops and reduce phosphate chemical fertilizer application. Bhattacharyya and Jha [35] have reported Azotobacter, Bacillus, Beijerinckia, Burkholderia, Enterobacter, Erwinia, Flavobacterium, Microbacterium, Pseudomonas, Rhizobium and Serratia as the most significant phosphate solubilizing bacterial genus. Phosphate solubilizing activity is related to the bacterial organic acids production, which chelate the cation bound to phosphate, thereby converting it to plants available form. [38] Who reported that plant growth promoting rhizo bacteria isolated from Alfa rhizosphere soils produce organic acids and also promote plant growth. Inoculation of crops with Phosphate solubilizing microbes has the potential application to reduce rates of phosphate fertilizer by $50 \%$ without significantly reducing crop yield and soil fertility [34].

Synthesis of phytohormones by endophytic bacterial species is another valuable endophytic plant growth promoting activities that affects growth of plants. IAA is a phytohormone that acts as an important signaling molecule which participates in the regulation of plant development including organogenesis, tropic responses such as phototropism, geotropism, cellular responses such as cell division, differentiation, enlargement, gene regulation, apical dominance, increases the rate of xylem, controls the processes of vegetative growth, initiates formation of lateral and adventitious roots, affects photosynthesis, and provides resistance to stressful conditions. Its production also increases plants root growth and root length resulting in larger root surface area giving the plant superior to access essential soil nutrients and water uptake from their surroundings. In the present study, $59.5 \%$ of endophytic bacterial isolates showed maximum production of IAA under laboratory condition. These endophytes could be used as bacterial bio stimulants to improve tef crop growth and yield as well as reduce dosage of chemical fertilizer application. [35] Who reported that plant inoculated with IAA producing PGP endophytic bacterial species have been used to stimulate seed germination, speed up root system, and increase root biomass as compared to non-inoculated one. Rhizobacterial species identified from the rhizosphere are more efficient auxin producers than isolates from the non-rhizosphere soil [36].

Most of the living organisms except microorganisms cannot take up atmospheric nitrogen. The atmospheric nitrogen is transformed into plant-usable forms by Biological Nitrogen Fixation (BNF) which changes atmospheric nitrogen into ammonia and making it accessible to the plants by the action 
of the complex nitrogenous enzymes synthesized by nitrogen fixing endophytic bacterial species [37]. Production of ammonia is another endophytic PGP bacterial property which has a signaling role between plant and bacterial interactions [37]. Produced ammonia can be taken up by plants as a source of nitrogen. In our study $9.7 \%$ of bacterial pure colonies were grown well on nitrogen free agar medium and ammonia production. These identified endophytic bacterial species or strains could be used as candidates for development inoculants to improve crop productivity and grain quality. The presence of ammonia producing PGP bacterial isolates in the roots and seed samples is an indicative process of ammonification were occurred in the rhizosphere

Indirect mechanism of plant growth promoting endophytes includes production of secondary metabolite which protects host plants from infection causing organisms by hydrocyanic acid production which is synthesized by the decarboxylation of glycine. HCN serves as an effective biological control agent against plant pathogens. HCN mainly stops electron transport chain and prevents energy supply to the cell, leading to death of the pathogen. In our study, $6.2 \%$ endophytic bacterial isolates showed positive results for HCN production. These native endophytes could be used as biocontrol agents to suppress pathogenic microorganisms and improve tef crops growth, yield as well as grain quality. HCN secreted by Pseudomonas fluorescent strain CHAO has been demonstrated to stimulate root hair formation and suppress back root rot caused by Thielaviopsis basicola in tobacco plant and improve yield (38).

Lytic enzymes act as agents for prevention of disease-causing organisms by secreting cell wall lytic enzymes. In the present study, $14.9 \%, 12.3 \%$ and $6.2 \%$ of the endophytic bacterial isolates showed effective result on synthesis of amylase, protease and cellulase, respectively and could be used as bacterial biocontrol agent to improve tef crops yield and reduce pesticides application. PGP endophytes that produce different types of lytic enzymes are effectively control plant pathogenic fungi and bacteria. Bull et al., (1988) [39] reported that Lysobacter and Myxobacteria produces lytic enzymes which have shown efficacy against some plant pathogenic fungi

Abiotic stress factors such as temperature, $\mathrm{pH}$, salinity and heavy metal contamination are the major factors that limit sustainable crops productivity and cause for more than $30 \%$ of worldwide crops damages [40]. Even though many plant growth-promoting bacteria endophytes show good results during laboratory evaluation, they fail in the field when applied as bioinoculants. One main reason for their failure is the stress imposed on them by the sudden change of soil physical, chemical and biological properties in the environment [41].

Salinity is one of the most important factors that unfortunately affect plant growth and yield. It affects about $20 \%$ of cultivated lands and $50 \%$ of irrigated areas are affected by salinity. Plants cultivated in saline soil commonly increase their ethylene production in the body of the plants in order to recruit programmed cell death. Soil salinity has been reported to decrease plants productivity by affecting plants metabolism, and total nitrogen contents. Our present study $36.9 \%$ of the bacterial isolates were grown well at $5 \% \mathrm{NaCl}$ w/v. Around $12.8 \%, 11.3 \%$ and $6.2 \%$ of bacterial isolates were grown well on $10 \% \mathrm{NaCl}, 15 \% \mathrm{NaCl}$ and $20 \% \mathrm{NaCl}$ w/v, respectively. These identified PGP endophytes showed ability to survive in a wide range of saline environment and thus, can improve tef crop productivity.

$\mathrm{pH}$ is another factor that affects life of the endophytic PGP bacteria species in the rhizosphere. In the present study, all of the tef endophytic bacterial isolates were grown well at $\mathrm{pH}-7$ and none of them were grown at $\mathrm{pH}-13$. Majorities (46.2\%) of bacterial isolates survived at $\mathrm{pH}-5$ and few (4.6\%) of them 
survived at pH-11. Temperature is also another plant growth limiting factors that affect PGP bacterial properties. In the present study, all of the identified tef endophytic bacterial isolates having PGP properties survived at 20 and $30^{\circ} \mathrm{C}, 36.4 \%$ of the isolates survived at $40^{\circ} \mathrm{C}$, and only $1 \%$ survived at $50^{\circ} \mathrm{C}$. No any endophytic bacterial isolates survived at $60^{\circ} \mathrm{c}$. This indicates that tef crops colonizing endophytic bacteria can tolerate a wide range of $\mathrm{pH}$ and temperature that confirmed as potential plant growth promoting bacteria to sustain crop productivity.

For seed germination and seedling growth evaluation, a seed of tef was inoculated with three tef endophytic PGP bacterial species (Pseudomonas fluorescens biotype G, Pseudomonas fluorescens and Pantoea agglomerans). Seed coating was made using single and consortium endophytic bacterial inoculation system. All of the tef seeds inoculated with potential endophytic bacterial species or strains were germinate tef seeds up to hundred percent on the third and fourth days after inoculation. Increase means shoot length (MSL) and roots length (RL) of the inoculated seeds up to 3 and $2.6 \mathrm{~cm}$ respectively and vigor index of seedling was measured from 460 to 520 on the last day of the experiment. Pradhan [42], reported that seeds inoculated with Bacillus sp. were significantly increased the germination, root and shoot length of the crops as compared to none inoculated one. Besides, Pieterse and Van Loon [43] reported that thirty percent growth improvement of Arabidopsis accession was achieved due to inoculation with Pseudomonas fluorescens. According to Woyessa and Assefa [44], inoculation of tef crops with Pseudomonas fluorescent increased mean root dry weight up to $39 \%$ percent, root shoot ratio up to $42 \%$, and grain yield up to $28 \%$ and also tef crops inoculated with Bacillus subtilis increased mean root dry weight of tef up to twenty eight, root shoot ratio up to nineteen nine percent and grain yield up to forty four percent.

\subsection{CONCLUSIONS}

These promising identified tef endophytic bacterial species or strains having PGP, biocontrol and abiotic stress tolerance properties are strong candidates for the development of bioinoculants as single strains or as consortia. They can be used to improve soil fertility, and conserve biodiversity. They have the potential to establish themselves as endophytes in tef roots and seeds, and can contribute to greater yield and productivity of crops in an eco-friendly manner. This strategy would work towards solving the problem of over-utilizing chemical fertilizers, reducing environmental pollution while increasing tef growth and yield.

\subsection{ACKNOWLEDGMENT}

I would like to thanks ministry of innovation and technology, AAU for financial support, Ethiopian biodiversity institute for materials and technical support

\subsection{REFERENCE}

[1]. Tsegay, Z., Assefa, F., Tefera, G., Alemu, T., and Gizaw, B. (2018). Characterization and identification tef (Eragrostis tef) seed endophytic bacterial species and evaluate their effects on plant growth promotion. J. plant pathol. Microbial, 9(4): 2157-7471. 
[2].Azevedo, JL., Maccheroni, WJR., Pereira, JO., and Araujo, WL. (2000). Endophytic microorganisms: a review on insect control and recent advances on tropical plants. Electron. $J$. Biotechnol: 3: 1e-4e.

[3].Etminani, F., and Harighi, B. (2018). Isolation and Identification of Endophytic Bacteria with Plant Growth Promoting Activity and Biocontrol Potential from Wild Pistachio Trees. Plant Pathol. J, 34(3): 208-217.

[4].Hallmann, JA. Quadt-Hallmann, W, F., MahaffeeJ., and Kloepper, W. (1997). Bacterial endophytes in crops. Can. J. Microbiol, 43:895-914.14.

[5].Reiter, B., and Sessitsch, A., (2006). Bacterial endophytes of the wildflower crocus albiflorus analyzed by the characterization of isolates and by a cultivation-dependent approach. Can.J.microbial, 52: 140-149.

[6].. Gamal, R.F. (2018). Recruitment of bacterial endophytes by host plants. Novel Research in Microbiology Journal, 2(6): 101-104.

[7].Shyam, LK., Pierre, MJ., and Sharon, LD. (2017). Bacterial Endophyte Colonization and Distribution within Plants. Journal of microorganism,5(77): 1-26.

[8].Hardoim, PR., van Overbeek, LS. Berg, G., Pirttilä, AM., Compant, S., Campisano, A., Döring, M., and Sessitsch, A., (2015). The hidden world within plants: Ecological and evolutionary considerations for defining the functioning of microbial endophytes. Microbiol. Mol. Biol. Rev,79: 293-320.

[9].Shyam, LK., Pierre, MJ., and Sharon, LD. (2017). Bacterial Endophyte Colonization and Distribution within Plants. Microorganisms,5(77): 1-26.

[10]. Berne, C., Ducret, A., Hardy, GG., and Brun, YV. (2015). Adhesions involved in attachment to abiotic surfaces by Gram-negative bacteria. Microbiol Spectr, 3(4):1-9.

[11]. Bulgarelli, D., Rott, M., Schlaeppi, K., Ver Loren van Themaat, E., Ahmadinejad, N., Assenza, F., Rauf, P., Huettel, B., Reinhardt, R., and Schmelzer, E. (2012). Revealing structure and assembly cues for Arabidopsis root-inhabiting bacterial microbiota. Nature,488: 91-95.

[12]. Meneses, CHSG., Rouws, LFM., Simoes-Araujo, JL., Vidal, MS., and Baldani, JI. (2011). Exopolysaccharide production is required for biofilm formation and plant colonization by the nitrogen-fixing endophyte Gluconacetobacter diazotrophicus. Mol. Plant-Microbe Interact, 24: 1448-1458.

[13]. Balsanelli, E., Serrato, RV., de Baura, VA., Sassaki, G., Yates, MG., Rigo, LU., Pedrosa, FO., de Souza, EM., and Monteiro, RA. (2010). Herbaspirillum seropedicae $\mathrm{rbB}$, and $\mathrm{rfbC}$ genes are required for maize colonization. Environ. Microbiol,12: 2233-2244. 
[14]. Balsanelli, E., Tuleski, TR., de Baura, VA., Yates, MG. , Chubatsu, LS., de Oliveira Pedrosa, F., de Souza, EM., and Monteiro, RA. (2013). Maize Root Lectins Mediate the Interaction with Herbaspirillum seropedicae via N-Acetyl Glucosamine Residues of Lipopolysaccharides. PLoS ONE, 8 (10), 1-9.

[15]. Hardoim, PR., van Overbeek, LS., Berg, G., Pirttilä, AM., Compant, S., Campisano, A., Döring, M., and Sessitsch, A. (2015). The hidden world within plants: Ecological and evolutionary considerations for defining the functioning of microbial endophytes. Microbiol. Mol. Biol. Rev, 79: 293-320.

[16]. Naveed, M., Mitter, B., Yousaf, S., Pastar, M., Afzal, M., and Sessitsch, A. (2014). The endophyte Enterobacter sp. FD17: A maize growth enhancer selected based on rigorous testing of plant beneficial traits and colonization characteristics. Biol. Fertil. Soils,50: 249-262.

[17]. Reinhold-Hurek, B., Maes, T., Gemmer, S., Van Montagu, M., and Hurek, T. (2006). Endoglucanase is involved in the infection of rice roots by the not-cellulose-metabolizing endophyte Azoarcus sp. strain BH72. Mol. Plant-Microbe Interact,19:181-188.

[18]. Olanrewaju, OS., Glick, BR., and Babalol, OO. (2017). Mechanisms of action of plant growthpromoting bacteria. World J Microbiol Biotechnol, 33(197): 1274-1291.

[19]. Gamalero, E., and Glick, BR. (2011). Mechanisms used by plant growth-promoting bacteria. In: Maheshwari D.K.K., editor. Bacteria in Agrobiology: Plant Nutrient Management. Springer; Berlin/Heidelberg, Germany, pp. 17-47.

[20]. Joe, MM., Devaraj, S., Benson, A., and Sa, T. Isolation of phosphate solubilizing endophytic bacteria from Phyllanthus amarus Schum \& Thonn: Evaluation of plant growth promotion and antioxidant activity under salt stress. J. Appl. Res. Med. Aromat Plants. 1-8.

[21]. Bhattacharjee, RB., Singh, A., and Mukhopadhyay, SN. (2008). Use of nitrogen-fixing bacteria as biofertilizer for non-legumes: Prospects and challenges. Appl. Microbiol. Biotechnol, 80:199209.

[22]. Mercado-Blanco, J., and Lugtenberg, B. (2014). Biotechnological Applications of Bacterial Endophytes. Curr. Biotechnol, 3:60-75.

[23]. Glick, BR. (2014). Bacteria with ACC deaminase can promote plant growth and help to feed the world. Microbiol. Res, 169:30-39.

[24]. Chen, YP., Rekha, PD., Arun, AB., Shen, FT., Lai, WA., and Young, CC. (2006). Phosphate solubilizing bacteria from subtropical soil and their tricalcium phosphate solubilizing abilities. Appl Soil Ecol, 34: 33-41. 
[25].Qureshi, M., Ahmad, Z., and Akhtar, N. (2012). Role of phosphate solubilizing bacteria (PSB) enhancing P availability and promoting cotton growth. J Animal Plant Sci.2012, 22:204-10.

[26].Brick, JM., Bostock, RM., and Silverstone's, SE. (1999). Rapid in situ assay for indole acetic acid production by bacteria immobilized on nitrocellulose membrane. Appl Environ Microbial, 57(2):535-538.

[27]. Jensen, HL. (1954). The Azotobacteriaceae. Bacteriological Reviews, 18:195-214.

[28]. Cappuccino, J., Sherman, N. (1992). Negative Staining Microbial Lab Manual,27-8.

[29]. Lorck, H. (1948). Production of hydrocyanic acid by bacteria. Physiol Plantarum, 1:142-6.

[30]. Punitha, A., Basil-Rose, MR., and Albino Wins, J. (2012), Prakash Shoba S, Mary Mettilda Bai1 S. Studies on amylase activity of an amylolytic bacterium isolated from estuarine soil. African Journal of Biotechnology, 11(42): 10015-10020.

[31]. Chang, W,T., Hsieh, CH., Hsieh, HS., and Chen, C. (2009). Conversion of crude chitosan to an anti-fungal protease by Bacillus cereus. World Journal of Microbiology and Biotechnology, 25: $375-382$.

[32]. Khianngam, S., Pootaeng-on, Y., Techakriengkrai, T., and Tanasupawat, S. (2014). Screening and identification of cellulase-producing bacteria isolated from oil palm meal. J App Pharm Sci, 4 (04): 090-096.

[33]. Santi, LP., Ai, Dariah., and dan Goenadi, DH. (2008). The increase in mineral soil aggregate stability by exopolysaccharide-producing bacteria (In Bahasa Indonesia). Journal Menara Perkebunan, 76 (2), 93 - 103.

[34]. Abdul-Baki, AA., and Anderson, J,D. (1973). Vigor determination in soybean seed by multiple criteria. Crop Sci, 13: 630-633.

[35]. Ogale, S., Yadav, K,S., and Navale, S. (2018). screening of endophytic bacteria from the pharmacologically important medicinal plant (Gloriosa Superba) for their multiple plant growthpromoting properties. The pharma innovation journal, 7(1):208-214.

[36]. Khan, AA., Jilani, G., Akhtar, MS., and Naqvi, SMS. (2009). Rasheed M. phosphorus solubilizing bacteria: occurrence, mechanisms and their role in crop production. Journal of agriculture and biological science, 1(1): 48-58.

[37]. Ryu, RJ., and Patten, CL. (2008). Aromatic amino acid-dependent expression of indol-3pyruvate decarboxylase is regulated by TyrR in Enterobacter cloacae UW5. Journal of bacteriology, 190(21): 7200-7208. 
[38]. Brick, JM., Bostock, RM., and Silverstone, SE. (2004). Rapid in situ assay for indole acetic acid production by bacteria immobilized on the nitrocellulose membrane. Appl, Environ. Microbial, 57: pp 535-538.

[39]. Howell, CR., Beier, RC., and Stipanovic, RD. (1988). Production of ammonia by Enterobacter cloacae and its possible role in the biological control of Pythium pre-emergence damping-off by the bacterium. Phytopathology, 78: 1075-1078.

[40]. Bunch, AW. and Knowels, CJ. (1982). Production of secondary metabolite cyanide by extracts of Achromobacterium violaceum. Journal of general microbiology,2675-2680.

[41]. Vessey, JK. (2003). Plant growth-promoting rhizobacteria as biofertilizers. Plant and Soil,255(2):571-586.

[42]. Bull, CT., Shetty, KG., and Subbarao, K, V. (2002). Interactions between Myxobacteria, plant pathogenic fungi, and biocontrol agents. Plant Dis, 86: 889-896.

[43]. Ahemad, M., and Kibret, M. (2014). mechanism and applications of plant growth-promoting rhizobacteria: a current perspective. J.K. S.U.S, 26; 1-20.

[44]. Kudan, R., Pant, G., Jadon, N., and Agrawal, PK. (2015). Plant growth-promoting rhizobacteria: mechanisms and current perspective. Journal of fertilizers and pesticides, 6(2):1-9.

[45]. Pradhan, A., Mohapatra, S., Mohanty, D., Samantaray, D., and Mishra, BB. (2017). Effect of polyhydroxyalkanoates accumulated plant growth-promoting Bacillus sp. On germination and growth of Mung Bean and Groundnut. Res J Pharm Biol Chem Sci, 8: 789-797.

[46]. Pieterse, C, MJ., and Van Loon, LC. (1999). Salicylic acid-independent plant defense pathways. Trends in Plant Science,4, 52-58.

[47]. Woyessa, D., and Assefa, F. (2011). Effects of Plant Growth Promoting Rhizobacteria on Growth and Yield of Tef (Eragrostis tef Zucc. Trotter) under Greenhouse Condition. Research Journal of Microbiology, 6 (4): 343-355. 